\title{
Koneksi Matematis Siswa dalam Menyelesaikan Masalah Open-Ended
}

\author{
Nazila Naf'atu Fina ${ }^{1}$, Cholis Sa'dijah ${ }^{1}$, Hery Susanto ${ }^{1}$ \\ ${ }^{1}$ Pendidikan Matematika-Universitas Negeri Malang
}

\begin{tabular}{l}
\hline INFO ARTIKEL \\
\hline Riwayat Artikel: \\
Diterima: 01-08-2020 \\
Disetujui: $25-08-2020$ \\
\hline
\end{tabular}

\section{Kata kunci:}

koneksi matematis; open-ended; koneksi pemodelan; koneksi konsep; koneksi prosedur

\author{
Alamat Korespondensi: \\ Cholis Sa'dijah \\ Pendidikan Matematika \\ Universitas Negeri Malang \\ Jalan Semarang 5 Malang \\ E-mail: cholis.sadijah.fmipa@um.ac.id
}

\begin{abstract}
The purpose of this study is to describe the mathematical connection processes of Junior High School students in solving open-ended problems. The type of this research is descriptive qualitative. The data of this research were obtained through tests and interviews. The mathematical connections processes can be seen when students solve open ended mathematics story problems. The connection processes are based on three types of connections, namely concepts connections, procedures connection, and modelling connections. The research concluded that students can use all known information and connect the information so that they get the solution. The process of students' mathematical connection is happened when the students were able to change the mathematical story problem into mathematical model and to connect mathematical concepts and procedures. However, in general, students only solve one solution even the problem was open ended. The reason is that the students rarely have experience in solving open ended mathematics problem.
\end{abstract}

ABSTRAK

\begin{abstract}
Abstrak: Tujuan penelitian ini untuk mendiskripsikan proses koneksi matematis siswa SMP dalam menyelesaikan masalah open-ended. Sumber data penelitian ini dari hasil tes masalah open-ended dan hasil wawancara. Koneksi matematis dapat dilihat ketika siswa menyelesaikan soal cerita matematika yang open ended. Proses koneksi matematis siswa dianalisis berdasarkan tiga tipe koneksi, yaitu koneksi konsep, koneksi prosedur dan koneksi pemodelan matematika. Penelitian ini menyimpulkan bahwa siswa dapat menggunakan informasi yang diketahui dan mengoneksikan informasi tersebut sehingga diperoleh penyelesaian. Proses koneksi matematis siswa terjadi ketika siswa mampu mengubah soal ke dalam model matematis dan siswa mampu menghubungkan konsep dan prosedur matematika. Tetapi umumnya siswa hanya menjawab satu penyelesaian walaupun soalnya open ended. Alasannya adalah karena siswa jarang memperoleh pengalaman menyelesaikan soal open-ended.
\end{abstract}

Kemampuan koneksi matematis merupakan hal yang penting dalam pembelajaran matematika (Stylianou, 2018). Pentingnya kemampuan koneksi matematis tampak pada berbagai dokumen kurikulum matematika yang antara lain pada tujuan pembelajaran matematika. (Aini dkk., 2016). Namun demikian, siswa yang sudah menguasai konsep matematika tidak selalu dapat melakukan regulasi koneksi matematis (Malasari, 2017 dan Utami dkk., 2019). Perlu adanya upaya gua melatih siswa untuk dapat mengelola kemampuan koneksi matematis agar siswa dapat menguasai hubungan antar setiap masalah matematis, masalah non matematis, dan masalah pada kehidupan sehari-hari (NCTM, 2000 dan Kristayulita dkk., 2018). NCTM (2000) menyebutkan bahwa ada lima kemampuan dasar matematika yang sesuai standar yakni pemecahan masalah, penalaran dan bukti, koneksi dan representasi. Mengacu pada lima standar kemampuan NCTM, tujuan pembelajaran matematika dalam Kurikulum 2013 pada hakekatnya, meliputi (1) koneksi antar konsep dalam matematika dan penggunaannya dalam memecahkan masalah, (2) penalaran, (3) pemecahan masalah, (4) koneksi dan representasi, dan (5) faktor afektif (Kemendikbud, 2016). Koneksi matematis merupakan kemampuan yang strategis untuk mendukung tercapainya tujuan pembelajaran matematika (Susanti, 2012 dan Sa'Dijah dkk., 2018).

Kesumawati (2014) berpendapat bahwa upaya yang dapat dilakukan guna mengembangkan konekasi matematis siswa di dalam kelas melalui pemberian konsep dan latihan. Selanjutnya, hal yang perlu dieksplorasi dalam koneksi matematis sebagai fokus penelitian berikutnya yaitu pengembangan koneksi dengan pemberian masalah open ended. Jenkins (2010) menyatakan bahwa salah satu cara agar siswa melibatkan koneksi matematis yaitu guru menggunakan tugas open ended. Ketika pemberian masalah open-ended, siswa diminta untuk menunjukkan langkah-langkah pengerjaannya untuk memperoleh jawaban dan 
memberi alasan sesuai dengan jawaban. Menurut Yuliana (2015) proses pembelajaran matematika menggunakan masalah openended dirasa meningkatkan dan mengembangkan siswa dalam berfikir tingkat tinggi. Nurdiansyah dan Muhsetyo (2018) menjelaskan bahwa siswa Indonesia membutuhkan banyak pengalaman dalam memecahkan masalah open-ended. Didukung Permendikbud RI No. 22 tahun 2016 tentang Standar Proses Pendidikan Dasar dan Menengah disebutkan bahwa prinsip pembelajaran yang digunakan dari pembelajaran yang menekankan jawaban tunggal menuju pembelajaran dengan jawaban yang memiliki kebenaran multi dimensi. Gambar 1 merupakan soal yang digunakan dalam observasi awal.

Suatu hari Sulaiman ingin pergi menggunakan ojek online. Dia bingung memilih Ojek Online G1 atau Ojek Online G2. Tarif Ojek Online G1 dan G2 sebagai berikut.

\begin{tabular}{|c|c|c|c|c|c|}
\hline \multirow[t]{2}{*}{ Ojek Online } & \multicolumn{5}{|c|}{ Tarif } \\
\hline & $1 \mathrm{~km}$ & $2 \mathrm{~km}$ & $3 \mathrm{~km}$ & $4 \mathrm{~km}$ & $\ldots \mathrm{km}$ \\
\hline G1 & Rp. 6.000,- & Rp. 7.500,- & Rp. 9.000,- & Rp. 10.500,- & Rp.... \\
\hline $\mathrm{G} 2$ & Rp. $2.500,-$ & Rp. 4.500,- & Rp. 6.500,- & Rp. 8.500,- & Rp. . \\
\hline
\end{tabular}

Sulaiman ingin pergi ke toko untuk membeli dua kue bolu dan dua toples nastar. Kue bolu dan nastar tersebut dijual di Toko A dan di Toko B. Toko A berjarak $5 \mathrm{~km}$ dari rumah Sulaiman, sedangkan Toko B berjarak 7 km dari rumahnya. Toko A menjual satu kue bolu Rp. 5.000,- sedangkan satu toples nastar Rp. 20.000,-. Toko B menjual dua kue bolu dan satu toples nastar Rp. 26.000,-, sedangkan satu kue bolu dan satu toples nastar harganya Rp. 22.000,-. Setelah membeli kue tersebut, Sulaiman pergi ke RS Tulungagung dengan naik ojek online yang berjarak $16 \mathrm{~km}$ baik dari Toko A maupun Toko B.

a. Toko mana yang lebih murah? Berapa rupiah yang harus dibayar Sulaiman untuk membeli kue tersebut?

b. Manakah ojek online yang dipilih Sulaiman untuk menghemati ongkos perjalanan? Berikan alasanmu.

c. Berapa biaya yang dikeluarkan Sulaiman untuk membeli kue dan membayar ojek online?

\section{Gambar 1. Masalah Open Ended dalam Observasi Awal}

Observasi dilakukan untuk melihat respons siswa terhadap masalah open ended dan indikator koneksi matematis. Observasi dilaksanakan pada bulan April tahun 2020. Peneliti menguji cobakan masalah open ended kepada 10 siswa. Berdasarkan hasil observasi di MTsN 1 Trenggalek diperoleh salah satu hasil penyelesaian masalah siswa yang banyak melakukan kesalahan dan tidak melakukan koneksi diberi kode siswa R, sedangkan siswa yang sedikit melakukan kesalahan dan tidak melakukan koneksi diberi kode T sebagaimana terlihat pada Gambar 2 dan 3.

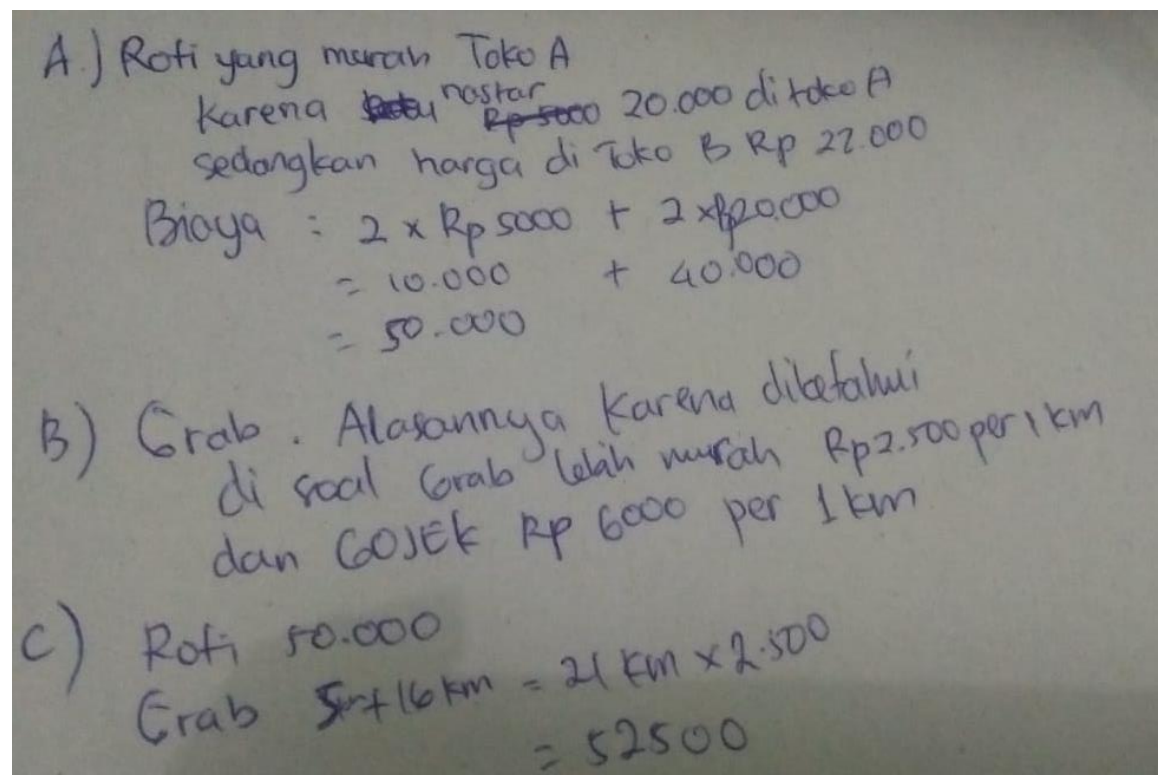

Gambar 2. Jawaban Siswa R 
Siswa R salah menjawab. Berdasarkan wawancara siswa $\mathrm{R}$ hanya membaca tanpa memahami maksud masalah openended matematika. Siswa $\mathrm{R}$ belum bisa memahami dengan baik maksud masalah open-ended matematika sehingga siswa $\mathrm{R}$ belum bisa mengoneksikannya. Jawaban yang ditulis siswa $\mathrm{R}$ menunjukkan respons yang tidak jelas dalam memberikan jawaban. Berdasarkan wawancara, hal ini dikarenakan siswa belum pernah mengerjakan masalah open-ended matematika.

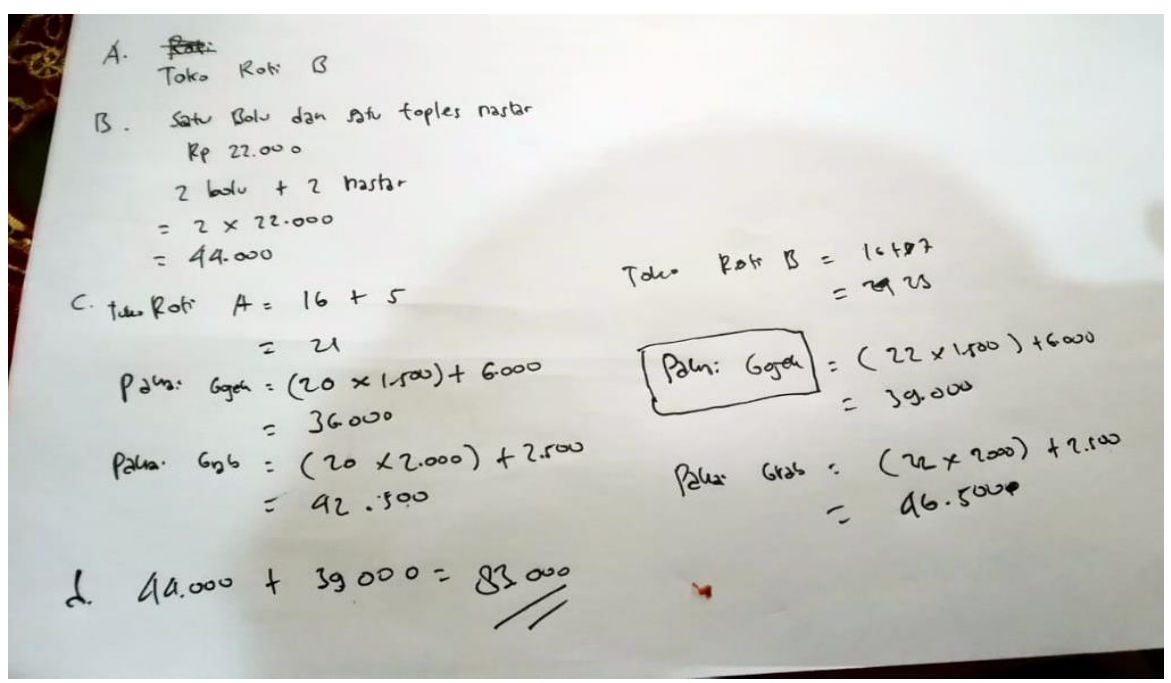

Gambar 3. Jawaban Siswa T

Siswa T menuliskan jawaban tanpa memberi alasan pada jawabannya. Siswa T juga belum bisa mengoneksikan hasil pekerjaannya pada materi matematika lainnya (Hidajat dkk., 2019). Berdasarkan wawancara, hal ini dikarenakan siswa belum pernah mengerjakan masalah open ended. Pada pembelajaran matematika, siswa jarang dituntut untuk mengoneksikan langkahlangkah penyelesaian masalah matematika selain materi yang sedang dibahas. Hal ini mengakibatkan kemampuan siswa dalam berfikir kreatif tidak berkembang. Tohir (2019) menyebutkan bahwa di tingkat sekolah menengah, siswa belajar lebih mendalam tentang hal berbicara dan menulis secara matematis. Oleh karena itu, koneksi matematis penting dibelajarkan kepada siswa.

Pada studi pendahuluan yang dilakukan penulis, ditemukan bahwa ada kecenderungan praktek pembelajaran yang mengutamakan pada pencapaian target sesuai isi materi buku atau materi yang harus dipelajari siswa. Sementara itu, buku wajib yang digunakan lebih fokus pasa soal dan materi ujian nasional sehingga pemecahan masalah dan koneksi matematis yang seharusnya mendapat perhatian lebih sering tidak diutamakan. Siswa kurang dapat menunjukkan ide-ide matematisnya. Salah satu upaya yang bisa dilakukan yaitu dengan memberi pembelajaran yang bersifat open-ended. Siswa difasilitasi dengan pemberian masalah open ended dalam pembelajaran matematika. Penelitian ini berfokus pada koneksi matematis siswa dalam menyelesaikan soal open-ended.

\section{METODE}

Penelitian ini menggunakan penelitian deskriptif dan pendekatan yang digunakan adalah pendekatan kualitatif. Penelitian dilakukan di MTs N 1 Trenggalek pada bulan Maret 2020. Subjek penelitian ini adalah dua siswa yang memiliki proses penyelesaian yang unik. Peneliti juga berdiskusi dengan guru kelas untuk memastikan bahwa siswa yang dipilih memiliki kemampuan komunikasi yang baik. Instrumen yang digunakan berupa lembar tes koneksi matematis siswa dan pedoman wawancara. Instrumen koneksi matematis berupa soal koneksi materi bangun ruang kelas VIII semester 2. Pedoman wawancara digunakan sebagai panduan peneliti ketika melakukan wawancara dengan subjek. Tes digunakan untuk mengetahui kemampuan koneksi siswa, sedangkan wawancara digunakan sebagai pelengkap informasi tambahan tentang proses koneksi yang dilakukan siswa. Instrumen yang digunakan dalam penelitian sudah divalidasi oleh ahli Pendidikan matematika yang berpendidikan S3 Pendidikan Matematika. Selanjutnya, proses koneksi matematis siswa dianalisis menurut tahapan Polya dan tiga tipe koneksi. Indikator dari masing-masing tipe koneksi ditunjukkan pada tabel 1.

Kemarin ibu baru membeli minyak goreng sebanyak $2156 \mathrm{ml}$. Karena tempat minyaknya plastik, ibu ingin menuangkannya ke dalam wadah. Bagaimana bentuk wadah dan berapa ukuran yang memungkinkan (dalam bentuk dimensi) wadah minyak goreng agar tidak tumpah dan menampung tepat sesuai dengan volume minyak? Jelaskan jawabanmu!

\section{Gambar 4. Soal Tes Koneksi}


Tabel 1. Indikator Koneksi Matematis Siswa dalam Menyelesaikan Soal Oppen Ended

\begin{tabular}{|c|c|c|}
\hline $\begin{array}{l}\text { Langkah-langkah } \\
\text { Polya }\end{array}$ & $\begin{array}{l}\text { Tipe Koneksi } \\
\text { Matematis }\end{array}$ & Indikator Proses Koneksi Matematis \\
\hline \multirow[t]{2}{*}{ Memahami masalah } & Pemodelan & $\begin{array}{l}\text { - Menentukan apa yang diketahui dan ditanya soal dalam bentuk visual, verbal atau } \\
\text { simbolik sehingga dapat memahami masalah matematika yang diberikan. }\end{array}$ \\
\hline & Konsep & $\begin{array}{l}\text { - Menghubungkan apa yang diketahui dan ditanya dengan konsep-konsep matematika } \\
\text { atau dengan ilmu lain sehingga dapat memahami masalah matematika yang diberikan. }\end{array}$ \\
\hline \multirow{2}{*}{$\begin{array}{l}\text { Membuat rencana } \\
\text { penyelesaian }\end{array}$} & Pemodelan & $\begin{array}{l}\text { - Menentukan rumus/ cara/ metode yang bisa digunakan untuk membuat rencana } \\
\text { penyelesaian sesuai soal yang diberikan dalam bentuk visual, verbal atau simbolik }\end{array}$ \\
\hline & Konsep & $\begin{array}{l}\text { - Menghubungkan konsep-konsep matematika seperti konsep pytagoras, konsep bangun } \\
\text { datar, konsep bangun ruang untuk membuat rencana yang akan digunakan. }\end{array}$ \\
\hline \multirow[t]{3}{*}{$\begin{array}{l}\text { Melakukan rencana } \\
\text { penyelesaian }\end{array}$} & Prosedur & $\begin{array}{l}\text { - Menyelesaikan model matematika yang telah dibuat sesuai dengan rencana yang telah } \\
\text { disusun } \\
\text { - Melakukan operasi perhitungan seperti mencari volume dan luas permukaan untuk } \\
\text { menyelesaikan rencana yang sudah dipilih. }\end{array}$ \\
\hline & Konsep & $\begin{array}{l}\text { - Menghubungkan konsep-konsep matematika untuk menyelesaikan soal yang } \\
\text { diberikan. }\end{array}$ \\
\hline & Pemodelan & - Menuliskan solusi matematis sesuai dengan soal yang diberikan \\
\hline $\begin{array}{l}\text { Mengecek kembali } \\
\text { hasilnya }\end{array}$ & Prosedur & $\begin{array}{l}\text { - Memeriksa kembali jawaban yang diperoleh dengan cara menghitung ulang setiap } \\
\text { langkah-langkah yang sudah dikerjakan. }\end{array}$ \\
\hline
\end{tabular}

Sumber: Adaptasi (Carson, 2007; Argarini, 2018; Sari \& Chandra, 2018)

HASIL

Subjek penelitian ini yaitu dua siswa yang memiliki cara berfikir dan proses penyelesaian yang unik. Keunikan subjek terletak pada cara berfikir untuk menemukan bentuk wadah yang sesuai dengan banyak minyak goreng yang ibu beli. Agar mempermudah, subjek diberi kode S1 mewakili siswa berinisial WF dan subjek diberi kode S2 mewakili siswa berinisial KA.

\section{Deskripsi proses koneksi Matematis Subjek 1 (S1)}

S1 memulai menyelesaikan dengan menuliskan apa yang diketahui pada soal dengan benar, dan apa yang diketahui dan ditanyakan soal dalam bentuk verbal dengan benar. S1 mengambil informasi bahwa ada minyak goreng sebanyak $2156 \mathrm{ml}$ yang akan dituang sehingga memerlukan wadah yang tepat. Tipe koneksi yang dilakukan S1pada tahap langkah pemecahan masalah berdasarkan Polya yaitu koneksi pemodelan. Seperti Gambar 5. Pemodelan S1 terhadap langkah memahami masalah.

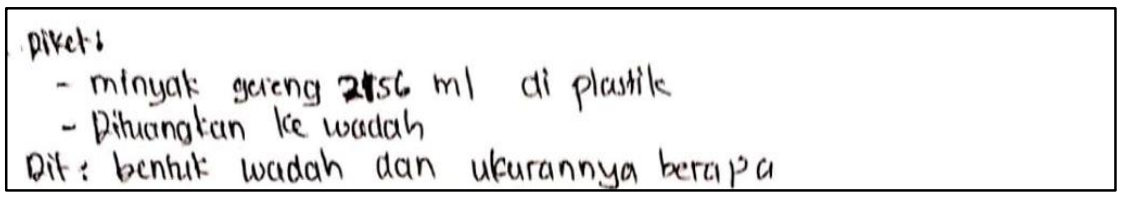

\section{Gambar 5. Pemodelan S1 terhadap Langkah Memahami Masalah Open-ended}

Pada langkah membuat rencana penyelesaian, S1 memilih tabung dengan ukuran tinggi $14 \mathrm{~cm}$ dan jari-jari $7 \mathrm{~cm}$ sebagai tempat yang cocok sebagai wadah minyak goreng. Siswa menentukan koneksi pemodelan di sini dengan menuliskan secara verbal. Namun ketika ditanya, dia sebelum menentukan jari-jari dan tinggi tabung dengan pemodelan visual karena siswa menggambar tabung dan mengira-ngira ukuran berapa yang sesuai dengan banyaknya minyak ibu. S1 juga dapat menghubungkan konsepkonsep matematika yang pernah dipelajari seperti mencari solusi penyelesaian dengan menggunakan rumus volume tabung.

\begin{tabular}{|c|}
\hline 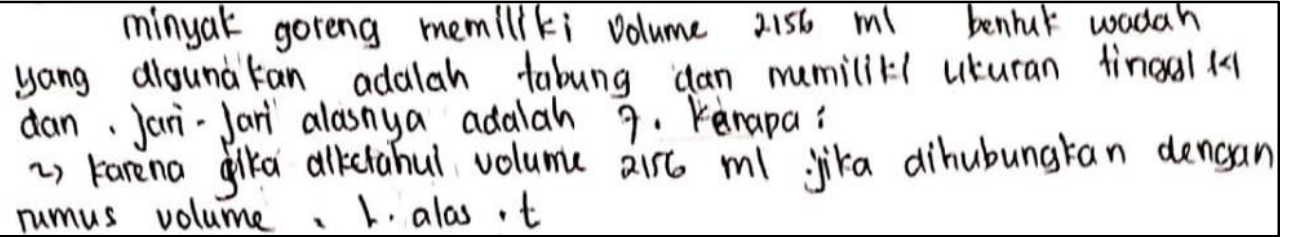 \\
\hline
\end{tabular}

\section{Gambar 6. Rencana Penyelesaian yang Dibuat S1 dalam Menyelesaikan Masalah Open-ended}

Peneliti melakukan wawancara untuk mengetahui lebih lanjut tentang proses membuat rencana siswa. Adapun kutipan wawancara seperti berikut. 


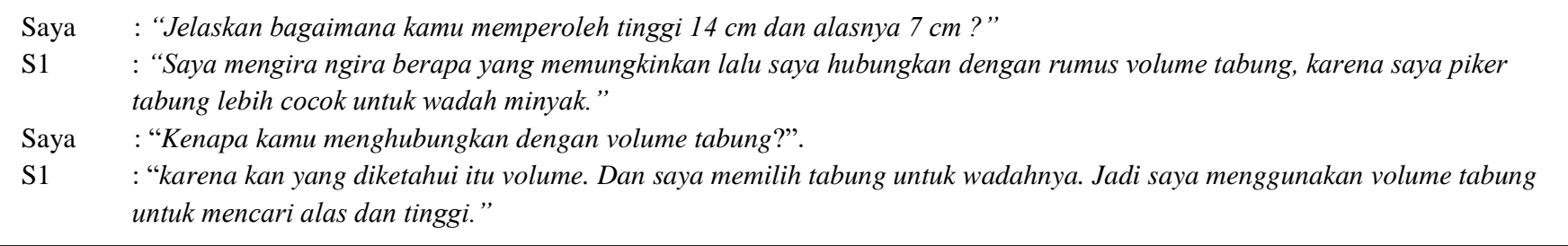

S1 melakukan rencana penyelesaian dengan menghubungkan informasi yang diketahui dengan simbol-simbol matematika seperti volume, luas alas dan tinggi. S1 menyelesaikan model matematika yang telah dibuat sesuai dengan rencana yang telah disusun. S1melakukan operasi perhitungan dengan mensubtitusikan informasi yang diketahui ke dalam rumus volume tabung. Sehingga diperoleh $r^{2} t=684$. S1 menjelaskan jika $r^{2} t=684$ maka jari-jari yang cocok untuk digunakan adalah 7 (dalam $\mathrm{cm}$ ) dan tinggi adalah 14 (dalam $\mathrm{cm}$ ). Hasil itu diperoleh dari menghubungkan sifat perhitungan perkalian dan pembagian antar ruas.

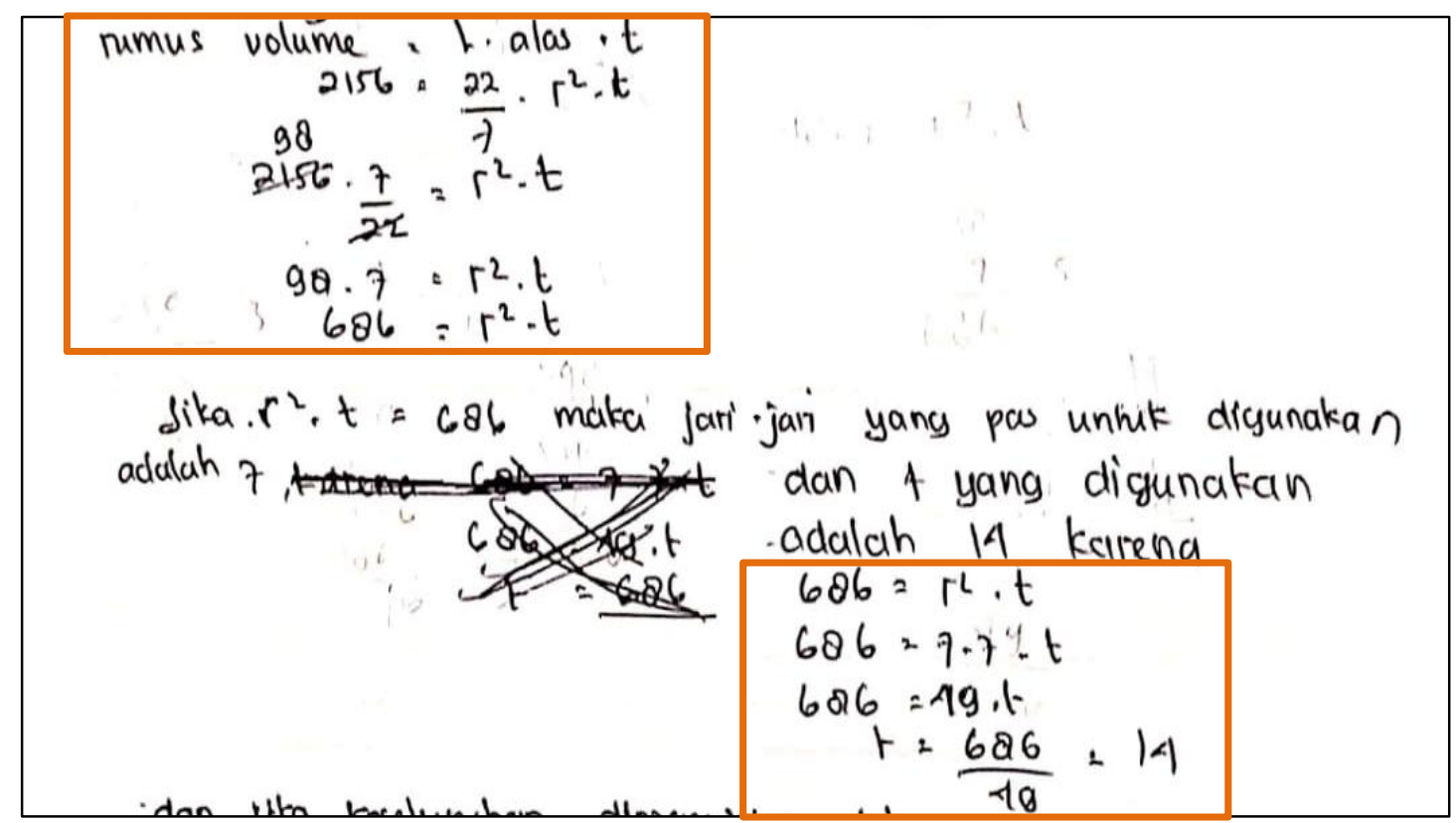

\section{Gambar 7. S1 Melakukan Penyelesaian Masalah Open-ended}

S1 melakukan pengecekan kembali hasil dengan mencoba memasukan ke rumus volume tabung. Memeriksa kembali solusi yang diperoleh menggunakan langkah-langkah yang sistematis dalam bentuk visual, verbal dan simbolik.

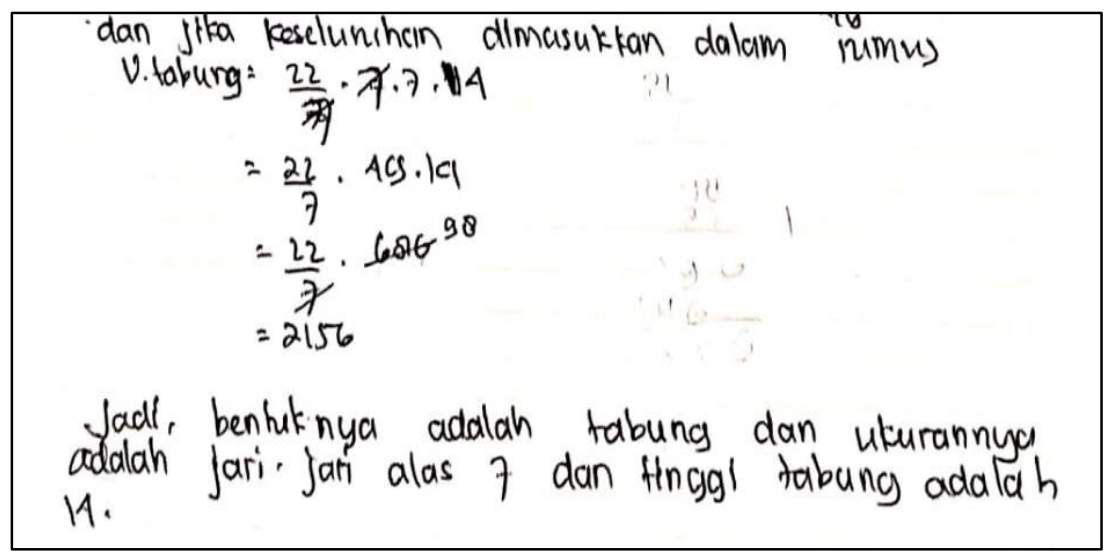

Gambar 8. S1 Melakukan Pengecekan Kembali Penyelesaian Masalah Open-ended 
S1 sudah dapat menuliskan solusi matematis sesuai konsteks masalah open-ended yang diberikan. S1 menuliskan jawaban akhir dengan bentuk kata-kata. Namun demikian, S1 hanya menjawab satu jawaban. Berdasarkan wawancara, S1 kurang mampu melihat keterkaitan topik matematika dan penerapannya dalam kehidupan sehari-hari.

Berdasarkan analisis terkait proses koneksi matematis S1, dapat dikemukakan bahwa S1 dapat memahami dan menghubungkan setiap informasi dengan pemodelan, konsep dan prosedur matematika yang dimiliki sehingga diperoleh jawaban akhir yang relevan. S1 dapat menuliskan jawaban akhir dengan benar melalui strategi mencoba-coba memasukan bilangan. S1 hanya menuliskan satu jawaban akhir yang seharusnya banyak kemungkinan jawaban yang bisa diperoleh. Lebih ringkas akan digambarkan struktur proses koneksi matematis S1dalam menyelesaiakna masalah open-ended seperti pada Gambar 9. Deskripsi dari proses koneksi matematis S1ketika menyelesaiakn soal cerita disajikan pada Tabel 2.

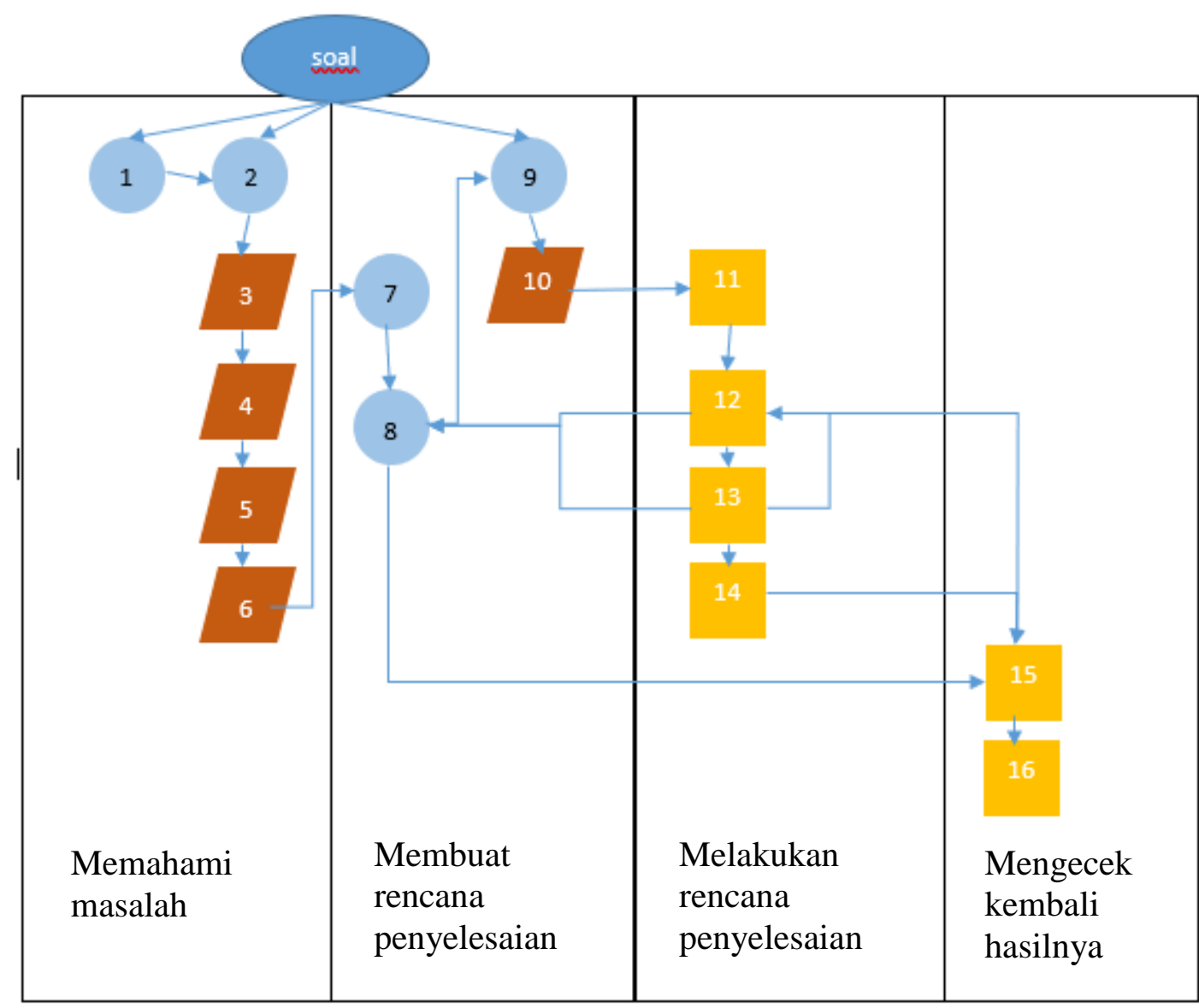

Keterangan:

\begin{tabular}{|c|c|}
\hline Soal cerita yang diberikan & $\begin{array}{l}\text { Hubungan antar } \\
\text { konsep }\end{array}$ \\
\hline \multicolumn{2}{|l|}{ Koneksi pemodelan } \\
\hline Koneksi Konsep & \\
\hline Koneksi prosedur & \\
\hline
\end{tabular}

Gambar 9. Diagram Alur Proses Koneksi Matematis S1 dalam menyelesaikan Soal Open-ended 
Tabel 2. Deskripsi Alur Koneksi Matematis S1 dalam Menyelesaikan Soal Open-ended

\begin{tabular}{cl}
\hline No & \multicolumn{1}{c}{ Deskripsi } \\
\hline 1. & Menerjemahkan banyaknya minyak goreng dalam bentuk verbal \\
\hline 2. & Menerjemahkan banyaknya minyak goreng di plastic yaitu $2156 \mathrm{ml}$ \\
\hline 3. & Menerjemahkan jika banyaknya minyak di plastik membutuhkan wadah dengan volume yang sesuai \\
\hline 4. & Menghubungkan banyak minyak goreng dengan berbagai bentuk yang memungkinkan, \\
\hline 5. & Menghubungkan berbagai bentuk-bentuk bangun ruang yang memungkinkan \\
\hline 6, & Menyatakan wadah tabung lebih cocok untuk wadah minyak sehingga digunakan volume tabung \\
\hline 7. & Memahami bahwa rumus volume tabung = Luas alas x t \\
\hline 8. & Memahami bahwa rumus volume tabung berupa lingkaran sehingga diperoleh rumus $V=\pi r^{2} t$ \\
\hline 9. & Menentukan jika jari-jari lingkaran kelipatan 7 maka $\pi$ menggunakan $\frac{22}{7}$ \\
\hline 10. & Menghubungkan konsep operasi perkalian \\
\hline 11. & Tidak dapat melakukan operasi aljabar dalam menentukan nilai $r^{2} t$ \\
\hline 12. & Menyatakan bahwa 686 merupakan $r^{2} t$ \\
\hline 13. & Mencoba-coba memasukan nilai $r$ dan tinggi, agar cocok denga napa yang diminta soal. \\
\hline 14. & Tidak dapat menghubungkan operasi aljabar dengan lengkap. \\
\hline 15. & Mengecek ulang jari-jari dan tinggi yang diperoleh kedalam rumus volume tabung, sehingga diperoleh bilangan sesui soal. \\
\hline 16. & Menuliskan wadah yang sesuai yaitu tabung dengan Panjang jari-jari $7 \mathrm{~cm}$, dan tingggi $14 \mathrm{~cm}$ \\
\hline
\end{tabular}

\section{Deskripsi proses koneksi Matematis Subjek 2 (S2)}

Koneksi matematis yang terjadi ketika S2 menyelesaikan masalah pada tahap memahami masalah yaitu ditemukan koneksi pemodelan, yaitu dimulai siswa menerjemahkan banyaknya minyak goreng dalam bentuk verbal dengan kata-kata. S2 terlihat menerjemahkan banyaknya minyak goreng di plastik yaitu $2156 \mathrm{ml}$. Dilihat dari hasil wawancara juga siswa S2 menerjemahkan bahwa banyaknya minyak di plastik membutuhkan wadah dengan volume yang sesuai. Tahap merancang rencana S2 juga menghubungkan banyak minyak goreng dengan berbagai bentuk yang memungkinkan yaitu menghubungkan berbagai bentuk-bentuk bangun ruang yang memungkinkan

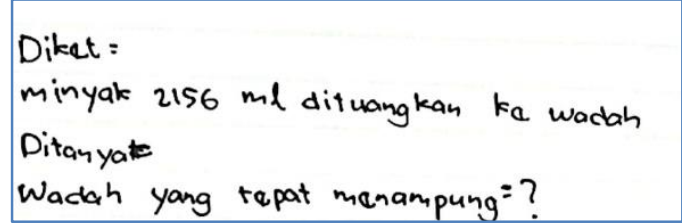

Gambar 10. Rencana Penyelesaian yang dibuat S2 dalam Merancang Penyelesaian Masalah Open-ended

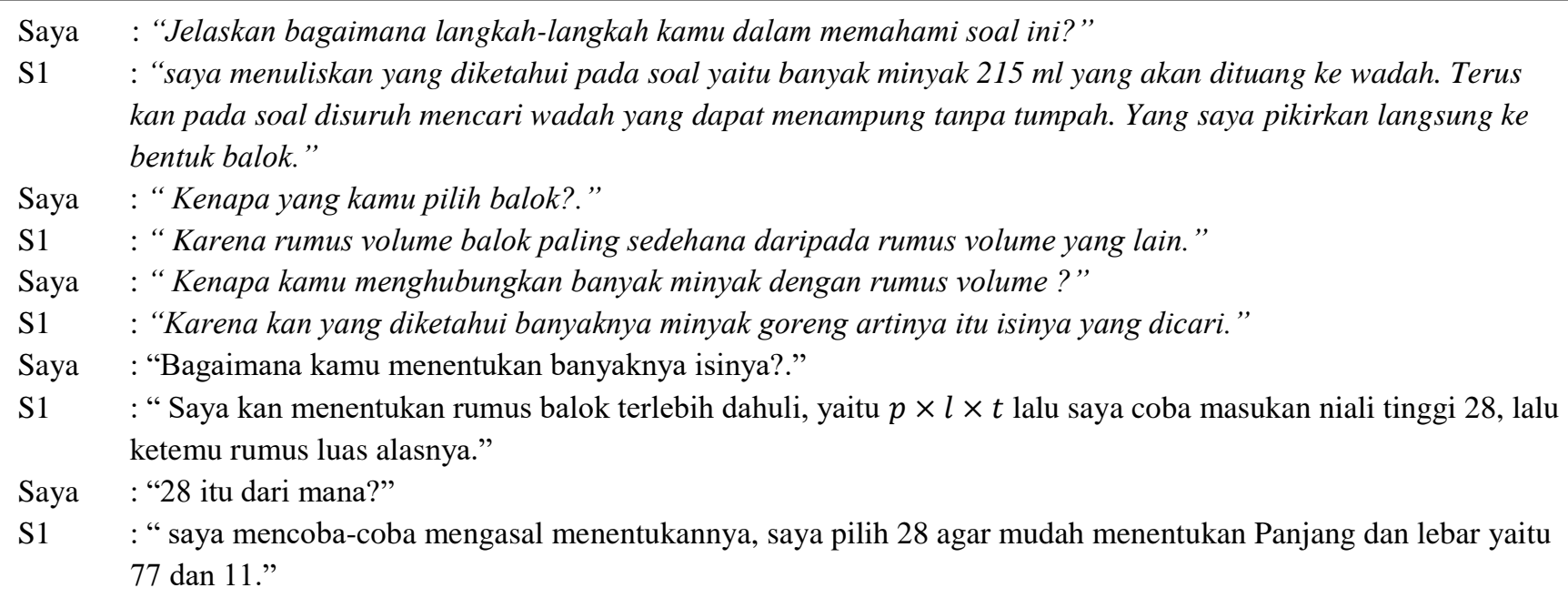

Menyatakan wadah berbentuk balok lebih cocok untuk wadah minyak sehingga digunakan volume balok. 


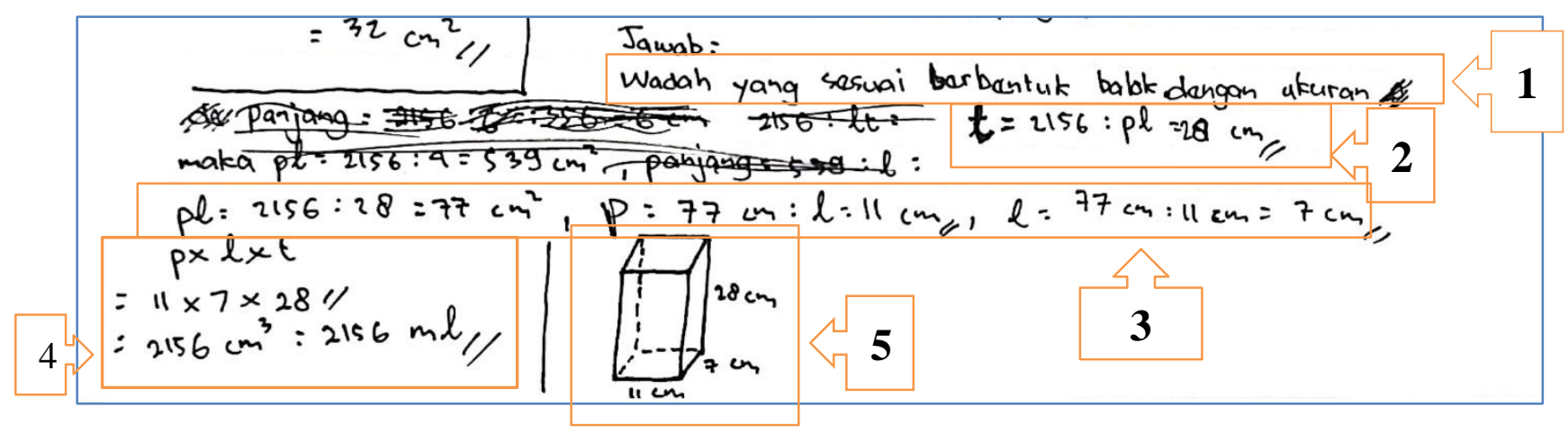

Gambar 11. Rencana Penyelesaian yang dibuat S2 dalam Menyelesaikan Masalah Open-ended

S2 memahami bahwa rumus volume balok yaitu $p \times l \times t$. Hal ini dilihat dari hasil pekerjaan S2 pada Nomer 4 . S2 menghitung operasi perkalian untuk menentukan tinggi dengan cara membagi volume dengan luas alas pada Nomer 2. Langkah itu diambil dari kutipan wawancara karena agar mempermudah ketika mencari luas alas yaitu panjang dikalikan tinggi. Namun S2 tidak memahami konsep pemodelan secara sistematis tapi mengerti konsep mencari panjang dan lebar dari hasil pembagian volume dan luas alas itu terlihat dari kutipan wawancara yaitu S2 melakukan teknik coba-coba dengan memasukkan satu-satu. S2 tidak memodelkan rumus volume dengan lengkap. S2 melakukan perkalian panjang, lebar dan tinggi sesuai hasil yang diperoleh S2 menyatakan hasil volume balok = banyak minyak dalam plastik yaitu $2156 \mathrm{~cm}^{3}=2156 \mathrm{ml}$. Berikutnya, S2 menerjemahkan dalam bentuk verbal kerangka balok berdasarkan panjang, lebar dan tinggi yang diperoleh dengan menggambarkan baloknya seperti Nomor 5 .

Tabel 3. Deskripsi Alur Koneksi Matematis S2 dalam Menyelesaikan Soal Open-ended

\begin{tabular}{|c|c|}
\hline No & Deskripsi \\
\hline 1. & Menerjemahkan banyaknya minyak goreng dalam bentuk verbal \\
\hline 2. & Menerjemahkan banyaknya minyak goreng di plastik yaitu $2156 \mathrm{ml}$ \\
\hline 3. & Menerjemahkan jika banyaknya minyak di plastik membutuhkan wadah dengan volume yang sesuai \\
\hline 4. & Menghubungkan banyak minyak goreng dengan berbagai bentuk yang memungkinkan, \\
\hline 5. & Menghubungkan berbagai bentuk-bentuk bangun ruang yang memungkinkan \\
\hline 6. & Menyatakan wadah berbentuk balok lebih cocok untuk wadah minyak sehingga digunakan volume balok \\
\hline 7. & Memahami bahwa rumus volume balok diperoleh rumus $p \times l \times t$ \\
\hline 8. & Menghitung operasi perkalian untuk menentukan tinggi dengan cara membagi volume dengan luas alas \\
\hline 9. & Tidak memahami konsep pemodelan secara sistematis tapi mengerti konsep \\
\hline 10. & Mencari Panjang dan lebar dari hasil pembagian volume dan luas alas. \\
\hline 11. & Tidak memodelkan rumus volume dengan lengkap \\
\hline 12. & Mengoperasikan bentuk perkalian dari Panjang, lebar dan tinggi sesuai hasil yang diperoleh \\
\hline 13. & Menyatakan hasil volume balok = banyak minyak dalam plastik yaitu $2156 \mathrm{~cm}^{3}=2156 \mathrm{ml}$ \\
\hline & $\begin{array}{l}\text { Menerjemahkan dalam bentuk visual kerangka balok berdasarkan Panjang, lebar dan tinggi yang } \\
\text { diperoleh. }\end{array}$ \\
\hline
\end{tabular}




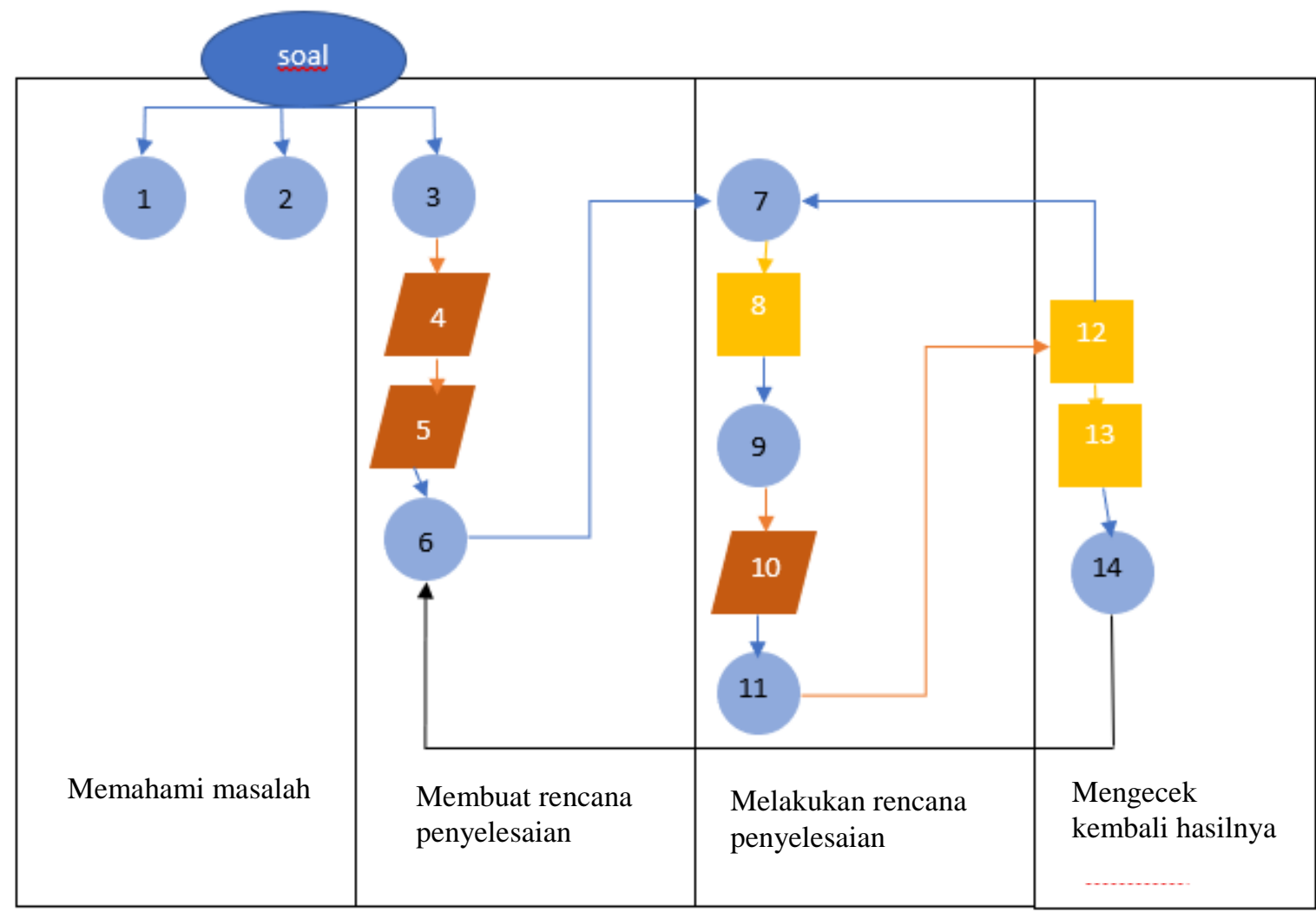

Keterangan:

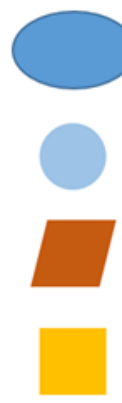

Soal cerita yang diberikan

Hubungan antar konsep

Koneksi pemodelan

Koneksi Konsep

Koneksi prosedur

\section{Gambar 12. Diagram Alur Proses Koneksi Matematis S2 dalam menyelesaikan Soal Open-ended}

Dari paparan data di atas, dapat dikemukakan bahwa S1 dan S2 dapat memahami permasalahan yang diberikan sampai dapat membuat model matematikanya dengan jawaban masing-masing. S1 dan S2 juga menghubungkan sesuai tipe koneksi matematis yaitu pemodelan, konsep dan prosesedur matematika sehingga memperoleh jawaban yang relevan. S1 dan S2 dapat melakukan koneksi pemodelan, koneksi prosedur dan koneksi konsep dalam menyelesaikan soal open-ended, Namun, S2 belum dapat memenuhi semua indikator koneksi matematis dalam menyelesaikan soal open-ended yang telah ditentukan. Siswa dapat melaksanakan koneksi pemodelan dengan menerjemahkan soal dan membuat model matematis. Namun, S1 masih kesulitan membuat pemodelan ke bentuk simbolik. S1 dan S2 juga dapat melakukan koneksi konsep sesuai kemampuan menghubungkan konsep-konsep matematika, seperti konsep volume bangun ruang dan konsep aljabar. S1 dan S2 melakukan operasi penjumlahan, pengurangan, perkalian, dan pembagian bentuk aljabar dengan tepat untuk dapat melakukan koneksi prosedur. S1 dan S2 masih cenderung menghafal prosedur sebagai aturan rutin yang biasa dilakukan tanpa memahami konsep yang mendasari adanya prosedur tersebut. S1 dan S2 masih belum dapat menuliskan sesuai dengan konsep yang ada. S1 dan S2 masih mencoba-coba dalam menentukan ukuran yang sesuai. S1 dan S2 juga belum terbiasa menemukan banyak jawaban ketika diberikan soal pemecahan masalah open-ended. Hal ini terlihat ketika diberi soal open-ended subjek hanya menuliskan satu kemungkinan jawaban saja. 


\section{PEMBAHASAN}

NCTM (2000) menyebutkan rambu-rambu pengenalan aspek koneksi dalam pembelajaran matematika di sekolah. Ada tiga standar penerapan koneksi di sekolah. Pembelajaran di sekolah diharapkan dapat membuat siswa mengenali dan menggunakan koneksi antar ide-ide matematis, memahami bagaimana ide matematika saling berhubungan dan saling membangun satu sama lain untuk menghasilkan keseluruhan yang koheren, serta mengenali dan menerapkan matematika dalam konteks di luar matematika. Dengan adanya standar ini, intrumen yang diberikan dibuat untuk menganalisa bagaimana tingkat pencapaian koneksi siswa dalam matematika.

Untuk indikator yang pertama, yaitu mengenali dan menggunakan koneksi, S1 dan S2 dihadapkan dengan permasalahan tentang volume minyak goreng. Berdasarkan jawaban dan hasil wawancara, terlihat bahwa siswa telah mampu mengenali hubungan antara volume dengan bangun ruang sehingga siswa dapat memanfaatkan rumus yang diketahuinya untuk menentukan jenis bangun ruang berdasarkan volume yang telah diketahui. Pemahaman ini membantu siswa untuk menentukan informasiinformasi yang perlu dimiliki sehingga hasil yang didapat sesuai dengan instruksi yang diberikan. Hal ini didukung hasil penelitian Sholihah dkk (2019) bahwa tanpa pemodelan matematika, soal cerita akan sulit untuk diselesaikan.

Selanjutnya, untuk indikator kedua, dimana siswa perlu memahami keterkaitan antar ide matematika. Pada instrumen ditunjukkan bahwa untuk dapat menentukan wadah yang digunakan beserta ukurannya, siswa perlu mencari informasi-informasi yang diperlukan, dalam hal ini siswa menggunakan formula tabung. Untuk menghitung volume tabung, siswa memerlukan informasi tentang tinggi dan jari-jari tabung. Berdasarkan jawaban siswa, untuk membuat volume tabung sesuai dengan volume air, siswa menentukan dahulu jari-jari dari tabung, kemudian menentukan tinggi tabung yang mungkin. Pada kegiatan menentukan tinggi tabung, terlihat bahwa siswa memanfaatkan cabang matematika lain yaitu aljabar. Strategi ini menunjukkan bahwa siswa menyadari keterkaitan antara geometri dan aljabar untuk memudahkannya menentukan strategi penyelesaian masalah. S1 dan S2 mempunyai pola berpikir yang berbeda dilihat dari jawabannya dan wawancara yang berbeda. Cara berpikir yang berbeda ini memengaruhi model matematika yang dibuat, seperti yang diungkap Syam dkk (2018) bahwa pemodelan matematis seseorang dipengaruhi oleh cara berpikirnya terhadap suatu situasi.

Untuk indikator ketiga, instrumen ini mengharapkan siswa mampu memahami makna dari hasil yang didapat dengan pertanyaan yang diberikan. Pada pengerjaan pencarian tinggi balok siswa tidak lengkap dalam menarik kesimpulan. Sehingga siswa belum bisa menghubungkan dengan kehidupan sehari-hari. Temuan tersebut didukung oleh hasil penelitian yang menyatakan bahwa sebagian besar siswa masih belajar konsep-konsep matematika secara umum dan menganggap bahwa konsep matematika tidak saling berkaitan satu-sama lain (Aini dkk., 2016). S2 kurang mampu menuliskan solusi matematis sesuai konteks soal. Hal tersebut menunjukkan bahwa S2 kurang dapat melihat keterkaitan antara matematika dan kehidupan sehari-hari (Handayani dkk., 2018)

\section{SIMPULAN}

Berdasarkan hasil analisis dan pembahasan di atas, dapat disimpulkan bahwa siswa menggunakan semua informasi yang diketahui. Siswa juga menghubungkan sesuai tipe koneksi matematis yaitu pemodelan, konsep dan prosesedur matematika sehingga memperoleh jawaban yang relevan. Siswa dapat melakukan koneksi pemodelan, koneksi prosedur dan koneksi konsep dalam menyelesaikan soal open-ended yang sudah diberikan. Namun, siswa belum dapat memenuhi semua indikator koneksi matematis dalam menyelesaikan soal open-ended yang telah ditentukan. Siswa dapat melaksanakan koneksi pemodelan dengan menerjemahkan soal dan membuat model matematis. Namun, siswa masih kesulitan membuat pemodelan ke bentuk simbolik. Siswa juga mampu melakukan koneksi konsep sesuai kemampuan menghubungkan konsep-konsep matematika, seperti konsep luas permukaan, konsep volume bangun ruang dan konsep aljabar. Siswa melakukan operasi penjumlahan, pengurangan, perkalian, dan pembagian bentuk aljabar dengan tepat untuk dapat melakukan koneksi prosedur. Siswa masih cenderung menghafal prosedur sebagai aturan rutin yang biasa dilakukan tanpa memahami konsep yang mendasari adanya prosedur tersebut. Siswa juga belum terbiasa menemukan banyak jawaban ketika diberikan soal pemecahan masalah open-ended. Terbukti ketika siswa memecahkan open-ended, siswa hanya menuliskan satu kemungkinan jawaban saja.

Saran yang dapat dikemukakan dari hasil penelitian ini yaitu siswa sebaiknya mempunyai pengalaman mengerjakan masalah open-ended yang berkaitan dengan kehidupan sehari-hari dan disajikan dalam bentuk soal cerita non rutin yang difasilitasi guru. Hal ini diharapkan akan sangat membantu siswa dalam memahami penerapan konsep matematika sehingga membuat pembelajaran matematika menjadi lebih bermakna. Ketika siswa diberikan masalah yang melibatkan konteks, siswa juga dapat menghubungkan dan menggunakan konsep-konsep dan prosedur matematika untuk menyelesaikan masalah non rutin sehingga bisa memperkuat kemampuan koneksi matematis siswa.

\section{UCAPAN TERIMA KASIH}

Terimakasih disampaikan kepada DRPM BRIN 2020 atas dana hibah Penelitian Tesis No. Kontrak 10.3.7/UN32.14.1/LT/2020 


\section{DAFTAR RUJUKAN}

Aini, K. N., Purwanto, P., \& Sa'dijah, C. (2016). Proses Koneksi Matematika Siswa Berkemampuan Tinggi dan Rendah Dalam Memecahkan Masalah Bangun Datar. Jurnal Pendidikan: Teori, Penelitian, dan Pengembangan, 1(3), 377-388. https://doi.org/10.17977/JP.V1I3.6164

Argarini, D. F. (2018). Analisis Pemecahan Masalah Berbasis Polya pada Materi Perkalian Vektor Ditinjau dari Gaya Belajar. Matematika Dan Pembelajaran, 6(1), 91. https://doi.org/10.33477/mp.v6i1.448

Carson, J. (2007). A problem with problem solving. Teaching Thinking without Teaching Knowledge, 17(2), 7-14.

Elly, M., Sa'dijah, C., Abd, Q., \& Lathiful, A. (2020). Practicality and Effectiveness of Realistic Mathematical Learning Materials to Support Mathematical Literacy Skill of Junior High School Students. AIP Conference Proceedings, 2215(1). https://doi.org/10.1063/5.0000844

Handayani, U. F., Sa'dijah, C., \& Susanto, H. (2018). Analisis Kemampuan Berpikir Kreatif Matematis Siswa SMP Dalam Menyelesaikan Soal Adopsi 'PISA.' Jurnal Math Educator Nusantara: Wahana Publikasi Karya Tulis Ilmiah di Bidang Pendidikan Matematika, 4(2), 143. https://doi.org/10.29407/jmen.v4i2.12109

Hidajat, F. A., Sa'dijah, C., Sudirma, \& Susisw. (2019). Exploration of students' arguments to identify perplexity from reflective process on mathematical problems. International Journal of Instruction, 12(2), 573-586. https://doi.org/10.29333/iji.2019.12236a

Jenkins, O. F. (2010). Developing teachers' knowledge of students as learners of mathematics through structured interviews. Journal of Mathematics Teacher Education, 13(2), 141-154. https://doi.org/10.1007/s10857-009-9129-9

Kemendikbud. (2016). Permendikbud Nomor 21 Tahun 2016 Tentang Standar Isi Pendidikan Dasar Dan Menengah (Lampiran). 1-234.

Kesumawati, N. (2008). Pemahaman Konsep Matematik dalam Pembelajaran Matematika. Pendidikan Matematika, 2(2), 229235.

Kristayulita, K., Nusantara, T., As'Ari, A. R., \& Sa'Dijah, C. (2018). Identification of Students Errors in Solving Indirect Analogical Problems Based on Analogical Reasoning Components. Journal of Physics: Conference Series, 1028(1). https://doi.org/10.1088/1742-6596/1028/1/012154

Malasari. (2017). A Development of Mathematical Connecting Ability of Students in Junior High School through a ProblemBased Learning with Course Review Horay Method A Development of Mathematical Connecting Ability of Students in Junior High School through a Problem-Based. https://doi.org/10.1088/1742-6596/755/1/011001

NCTM. (2000). Executive summary - Principals and standards for school mathematics. 1-6. https://doi.org/10.1111/j.19498594.2001.tb17957.x

Nurdiansyah, I., \& Muhsetyo, G. (2018). Pengembangan Lembar Kegiatan Siswa Berbantuan Tangram Bercirikan Open-Ended pada Pokok Bahasan Segiempat dan Segitiga Kelas VII SMP. Jurnal Pendidikan:Teori, Penelitian, dan Pengembangan, 3(6), 829-837.

Sa'Dijah, C., Afriyani, D., Subanji, Muksar, M., \& Anwar, L. (2018). Assessing students' pseudo-mathematical translation using translation-verification model. AIP Conference Proceedings, 2014(October), 1-10. https://doi.org/10.1063/1.5054548

Sari, F. K., \& Chandra, T. D. (2018). Proses Koneksi Matematis Siswa SMP dalam Menyelesaikan Soal Cerita. Jurnal Pendidikan:Teori, Penelitian, dan Pengembangan, 3(6), 715-722.

Sholihah, U., Nusantara, T., Sa'Dijah, C., \& Susanto, H. (2019). The Ability of Students' Visual Thinking in Solving Integral Problems. Journal of Physics: Conference Series, 1157(3). https://doi.org/10.1088/1742-6596/1157/3/032090

Stylianou, D. A. (2013). An Examination of Connections in Mathematical Processes in Students 'Problem Solving : Connections between Representing and Justifying. 2(2), 23-35. https://doi.org/10.5539/jel.v2n2p23

Susanti, E. (2012). Meningkatkan Penalaran Siswa melalui Koneksi Matematika. Prosiding, 8(7), 978-979.

Syam, H., Sutawidjaja, A., Sa'dijah, C., \& Abadyo. (2018). The Critical Thinking Profile of Junior High School Students in Solving Geometry Problems. International Journal of Multidisciplinary Research and Development, 5(7), 33-37.

Tohir, M. (2019). Hasil PISA Indonesia Tahun 2018. Paper of Matematohir, 2(1), 1-2. https://doi.org/10.31219/osf.io/pcjvx

Utami, A. D., Sa'dijah, C., Subanji, \& Irawati, S. (2019). Students' Pre-Initial Mental Model: The Case of Indonesian FirstYear of College Students. International Journal of Instruction, 12(1), 1173-1188. https://doi.org/10.29333/iji.2019.12175a

Yuliana, E. (2015). Pengembangan Soal Open Ended pada Pembelajaran Matematika untuk Mengidentifikasi Kemampuan Berpikir Kreatif Siswa. Prosiding Seminar Nasional Pendidikan Matematika (SNAPTIKA) 2015, Palembang 16 Mei 2015 